\title{
FORMS OF ADDRESS AMONG LAW STUDENTS IN 19TH CENTURY SÃO PAULO: SYMMETRICAL RELATIONSHIPS
}

\section{O TRATAMENTO ENTRE OS ACADÊMICOS NA SÃO PAULO OITOCENTISTA: AS RELAÇÕES SIMÉTRICAS}

\author{
Marilza de OLIVEIRA ${ }^{1}$ \\ Enedino SOARES ${ }^{2}$
}

\begin{abstract}
This paper, which traces the forms of address within the point of view of the sociohistorical analysis of language, is based on the theory of language socialization (OCHS, 1996) and the theory of the interpretation of cultures (GEERTZ, 2011), and is inspired by the approach of communities of practice (ECKERT, 2000). The theories defend that the apprehension of any meaning assigned by a particular group depends on a dense description that provides an understanding of the web of meanings in which the subjects are immersed. Methodologically, it is based on the framework of the dimensions of power (BROWN; GILMAN, 1960), on the evidential paradigm (GINZBURG, 1989), and the proposal for the comparison on the grand scale developed by Elias (2001). The interpretative analysis of the forms of address allowed the separation of linguistic indicators from the uses that expressed sensitivities, correlating language and socio-cultural structure. The analysis shows that você is used to express aggressive behavior and fit of rage; você, in Bakhtinian view of carnival (BAKHTIN, 1987), sets the low in the place of the high in the address scale.
\end{abstract}

Keywords: Stylistic use. Social behavior. Linguistic variation. Forms of address.
Resumo: Este artigo, que tem como tema as formas de tratamento dentro do viés da análise sociohistórica da linguagem, é alicerçado na abordagem de comunidade de prática (ECKERT, 2000) e na teoria da interpretação das culturas que concebe $\mathrm{O}$ comportamento humano como uma ação simbólica (GEERTZ, 2011). Ambas as abordagens defendem que a apreensão de qualquer significado atribuído por um grupo depende de uma descrição densa que permite uma compreensão da rede de significados na qual os sujeitos estão enredados. Metodologicamente, se apoia no quadro da dinâmica das relações humanas estruturado pelas dimensões do poder (BROWN; GILMAN, 1960), no paradigma indiciário (GINZBURG, 1989) e na proposta da comparação por escalas desenvolvida por Elias (2001). A análise interpretativa das formas de tratamento permitiu separar os indicadores linguísticos dos usos que expressavam sensibilidades, correlacionando língua e estrutura sociocultural. A análise mostra que, usado para expressar comportamento agressivo e ataque de fúria, você, na visão Bakhtiniana de carnavalização, sinaliza o baixo na escala de tratamento.

Palavras-chave: Uso estilístico. Etiqueta. Variação linguística. Formas de tratamento.

1 Universidade de São Paulo (USP), São Paulo, São Paulo, Brasil; marilza@usp.br; https://orcid.org/0000-0003-3279-3423

2 Universidade de São Paulo (USP), São Paulo, São Paulo, Brasil; enedius@hotmail.com; https://orcid. org/0000-0002-8665-3373 
- | Forms of address among law students in 19th century São Paulo: symmetrical relationships

\section{Introduction}

The study of speech from a past era is one of the great challenges to be faced by researchers owing to the absence of a natural situation of linguistic communication. Even if we look for material marked by casual styles, such as personal letters and plays that represent the characters' speech, there is always the danger of bias in the written language and the danger of the observer's point of view. Without the possibility of an interview situation, it is also not possible to collect a large amount of material representing different social categories and not even to elicit realizations of the linguistic variable. No less problematic is the issue of evaluating the linguistic variable, as there is no way to apply perception tests to measure the acceptability of the variants nor to apply production tests to understand speakers' choices. Such obstacles have been partially overcome with the principle of uniformity, according to which forces acting in the present had a similar weight in the past, and vice versa. In a way, the accumulation of works on the same theme, such as the use of forms of address in different samples, allows one, thanks to the application of this principle, to compose a broad linguistic panel and to outline, within a macrosocial framework, hypotheses about the motivations (cause, period and place) and paths of change.

The literature shows that você (you) is the result of the grammaticalization of the nominal address Vossa Mercê. Initially, Vossa Mercê was used to highlight and bring out the king's kindness gratia. This honorific address was subsequently extended to the nobility and it didn't take long to be appropriated by an increasing number of persons that belonged to the upper class despite the lack of lordship (CINTRA, 1972). Concurrent to the spread of Vossa Mercê, phonetically simplified variants emerged without honorific value among which was você used between equals of a lower class and by a superior to an inferior, affectionally but several times in a pejorative manner (NASCENTES, 1956; LUFT, 1957). In European Portuguese, although, você is used at work with colleagues with whom one is not in familiar terms (CARREIRA, 2005).

According to recent researches, there are two readings of the honorific value of Vossa Mercê in Brazil. The first one argues that it would not be settled in Brazil because at the start of Portuguese settlement this value would already have disappeared (FARACO, 1996) due to the lack of social conditions that regulated the rigid use of these address forms (MENON, 2006). The absence of schools of higher level during Brazil's colonial era would have inhibited the implementation of honorific value for this nominal address (MENON, 2006). Another interpretation is given by Lopes and Duarte (2003). Based on plays produced in Rio de Janeiro, they argued that Vossa Mercê and você kept the honorific 
value till the eighteenth century, both forms were used in the interpersonal relationships between inferior and superior, in both directions. During the nineteenth century, these nominal forms were pronominalized. Vossa Mercê kept the reverence and was used by inferior to superior; você was restricted to address the inferior by the superior. This analysis matches the results of the first systematic work on forms of address in Brazilian Portuguese that points to the end of the nineteenth century as a crucial period for the pronominalization of você (you) (BIDERMAN, 1975).

Resuming the theme within the Labovian sociolinguistic approach, several works carried out from a diachronic perspective have shown the variation between the second person singular pronoun $t u$ (you.sg) ${ }^{3}$ and the indirect form você. The study of the two pronouns in Brazilian theatrical plays from the 18th and 19th centuries revealed an increase in the frequency of the form você (DUARTE, 1993, RUMEU, 2008, and others). Lopes and Duarte (2003) observed that the use of $t u$ reaches $90 \%$ in the first half of the 19th century, polarizing with você $(10 \%)$. However, in the second half of the 19th, there is a deflection of tu whose frequency indexes are around $60 \%$ and the beginning of the rise of voce, which is around $20 \%$. Focusing on symmetrical relations, the authors observed that the form voce, as opposed to $t u$, presents higher rates among members of the lower class.

Machado (2018) also analyzed allocutive forms in plays written in Rio de Janeiro between the 19th and 20th centuries. In symmetrical and solidary relations, the tu dominates in the third quarter of the 19 th century $(71 \%)$, retreats in the fourth quarter $(17 \%)$, returns to gain frequency in the first quarter of the 20th century ( $75 \%)$. The reasons for the oscillation in the use of $t u$ in interpersonal relationships are unclear.

The study of personal letters from Rio de Janeiro showed the predominance of $t u$ $(72 \%)$ in the familiar and intimate address in symmetrical relationships from the 18th to 19th centuries. In descending asymmetric relationships, family roles interfere in the choice of address: children are treated by você (94\%) and grandchildren by $t u$ (70\%) (LOPES; DUARTE, 2007; SILVA; BARCIA, 2000).

In summary, these studies indicate that: i) at the end of the 19th century você started to compete with $t u$; ii) você was used more in symmetrical relationships between lower class; iii) você was used in the descending asymmetric relationship; iv) in some Portuguese villages você was used to insult the hearer.

$3 T u$ is a singular second-person pronoun in Portuguese. It can be compared to the archaic English pronoun "thou", although there is no relationship between the historical and social contexts in which both were used. (T.N.) 
- | Forms of address among law students in 19th century São Paulo: symmetrical relationships

If we take into account the ongoing Portuguese immigration ${ }^{4}$, a process characterized by population groups of the lower class coming from remote areas of Portugal mainland and islands (KLEIN, 1989; SILVA, 2012; FREITAS, 2006; OLIVEIRA, 2015), we question whether você concurred with $t u$ in symmetrical relationships and whether the insulting remark of você was in use in Brazil in the nineteenth century.

To answer this question, we made a panoramic analysis of the forms of address expressed on young people utterances in 14 plays by Joaquim José de França Júnior. As five of these plays ${ }^{5}$ (MHC, IC, MC, LB e MP) were shown to be representative of the speech attitude used by young people in different situations, we focused on them. We took as a parameter of the cult speech the MHC and IC comedies that were set in the student life of the School of Law of São Paulo and carried out a survey of the forms of address used among equals. It is important to note that this was the first school of higher education in Brazil. Created in 1828 to prepare youngsters to be engaged in key administrative posts of the newly independent State ${ }^{6}$ (ADORNO, 1988), the School of Law was a very important place to the symbolic identity construction of the group whose language was used as a reference for other schools (RIBEIRO, 2010; 2015; SILVA, 2012). So, if in some scenes the students' behavior was full of irreverence, in others it revealed the ranking meaning of the forms of address that shaped their reality.

As we shall see below, the author himself had studied Law in São Paulo in the second half of the 19th century. Following, we resort to the plays in which there were young persons with higher education inserted into the labour market, to capture the ranking steady of the meaning of address forms.

Lastly, we analysed some plays in which there were young people without higher education and that belonged to different social classes to establish a comparison between the speak of cult and non-cult young people. The scope of this work is to answer the questions: Did você have a symbolic meaning in the 19th century? If so, what did this stylistic usage try to accentuate? To answer these questions, we will consider the social and

\footnotetext{
4 The term "immigrant" is used in a generic sense to refer to the Portuguese displacement before and after Brazil's Independence.

5 Plays analysed: $\mathrm{MHC}=$ "Meia hora de cinismo" (Half an Hour of Cynicism); IC = "Ingleses na costa" (Englishman on the Coast); $M C=$ "O Ministério caiu" (The Cabinet has been dissolved); LB= "Lotação dos bondes" (Tram at capacity); $\mathrm{MP}=$ "Maldita parentela" (Damned poor relative); DR= "As doutoras" (The female doctors); CFD= "Como se fazia um deputado" (How one became a Member of parliament); AAP= "Amor com amor se paga" (Love is rewarded by love); TA= "Tipos da atualidade" (Present patterns); TB= "Tipo brasileiro" (Brazilian pattern); DPS= "Dois proveitos em um saco" (Two profits in one shot); CJ= "Clube Jácome" (Jacome Club); DLT= "Direito por linhas tortas" (Straight with crooked lines); DF= "Defeito de família" (A family defect).

6 The Independence of Brazil took place in 1822.
} 
affective or emotional dimensions of the address forms. This suggests that "it is essential to match selected linguistic forms to the context of interaction" (CARREIRA, 2005, p. 310).

\section{Theoretical-methodological assumptions}

Brown and Gilman (1960) maintain that the dynamics of human relations are structured by the dimension of power, based on distance and lack of reciprocity, and by the dimension of solidarity, emphasized in actions of equality, intimacy, and reciprocity. The authors base themselves on the complementarity of forms of address in German, in which the "Sie" form is used in relationships with a person from whom a certain social distance is maintained and the pronoun " $\mathrm{du}^{\mathrm{u}}$ " between friends and family in situations of informality. In general terms, the dimension of power explains the rule of non-reciprocity $T-V^{\prime}$ among people who do not belong to the same space of power regulated by different social factors (age, gender, origin, profession, training, purchasing power). In these asymmetric interpersonal relationships, in which the notion of hierarchical power is imposed, the higher ranking participant uses $\mathrm{T}$ and receives $\mathrm{V}$, a pronoun that symbolically represents the notion of distance, formality, and reverence.

A symmetrical interpersonal relationship implies reciprocal address in $\mathrm{V}-\mathrm{V}$ or $\mathrm{T}$ T. However, this equal address is not always synonymous with closeness or intimacy: if $T$ is used between equals and intimates, $\mathrm{V}$ can be adopted between equals, who are distant, reflecting, in this case, a symmetrically non-solidary relationship.

Works in the Labovian sociolinguistics tradition mold have adopted this framework and applied these relational measures to the addressers and addressees of letters and different characters in plays. Such research has proven quite fruitful in composing a linguistic panorama, allowing to map variation and change in the forms of address implemented by the lowest social classes. However, there is still a gap regarding the weight of the stylistic factor whose address requires a broader analysis of the social structure and social functions that engender codes and behaviors to recover the social and expressive meaning of the interlocutive forms.

Such a proposal assumes that language is a system of symbolic resources and that "language practices encode and socialize information about society and culture" (OCHS, 1996, p. 409). This process is formalized by the indexical principle: "socialization is in part a process of assigning situational, i.e., indexical, meanings [...] to particular forms") (OCHS,

7 Although the reflections were based on German, the authors adopt the $T$ and $V$ forms originating from the Latin Tu and Vos. 
- | Forms of address among law students in 19th century São Paulo: symmetrical relationships

1996, p. 410). In a certain way, this principle constitutes the foundation of the notion of community of practice explored by Eckert and McConnel-Ginet (MEYERHOFF; HOMES, 1999) to investigate the linguistic variation between individuals who share social practices in which their identities are built. Eckert (2000) takes as an example the formation of a band whose members negotiate the musical repertoire, choose ways of dressing and behaving to create their style, thus building their identities as well as the identity of the band itself.

Considering that linguistic behavior is one of the constituent facets of a community of practice's style, it is expected that the investigation of the process of forming social meanings will provide clues to explain linguistic variation, after all, human language, to paraphrase Max Weber (GEERTZ, 2011, p. 4), is entangled in the webs of meaning woven by itself. The pursuit of these webs of meaning demands, therefore, an approach that does not end in the social categories but that is attentive to the social dynamics that produce their own symbolic systems.

The theoretical framework of interpreting cultures (GEERTZ, 2011) sees human behavior as a symbolic action and, as such, poses a fundamental question: what is the importance of what is being transmitted with the realization of a given conduct? Within the research framework proposed here, the question can be rephrased as: What is transmitted within a given address formula and what is the value of você?

The answer to this question requires immersion in the universe that is being described to "pay attention to behavior, and with accuracy, as it is through the flow of behavior - or, more precisely, social action - that cultural forms find articulation" (GEERTZ, 2011, p. 12). The search for regularities and irregularities is not sought to build spreadsheets of conduct, but to make detailed descriptions that can lead to unveiling some "socially established meaning structures" (GEERTZ, 2011, p. 9), which is done "creatively and imaginatively within them" and not by studying them. This proposal is not, therefore, a mere adjustment of perspective or regulation of the observer's paradox to obtain a more reliable portrait, but a redefinition of the object of study itself, which is not a community but inside the community to acquire "familiarity with the imaginative universe within which the actions are determined milestones" (GEERTZ, 2011, p. 9). In our view, this change of perspective approximates the interpretative framework to the notion of community of practice (ECKERT, 2000).

To attest to the dissonant use of a form of address is indeed part of the portrait of the structures of meaning, but recovering their symbolic value is above all a task that allows one to recompose the "coordinates of the experienced world" (GEERTZ, 2011, 
p. 20). This process is part of the evidential paradigm that focuses on examining the most negligible details that provide clues for reading the linguistic weave: "We could compare the threads that makeup [this paradigm] to the threads of a rug. At this point, we see them forming a dense and homogeneous pattern. The consistency of the design is verifiable by looking at the carpet in different directions" (GINZBURG, 1989, p. 170).

Regarding the symbolic value of the forms of address, it is worth remembering that social attributes socially approved in a given culture constitute the line of action and conduct that a person claims for himself to adopt a defensive position to preserve face from some threat or threats, resulting from: i) actions taken without intention or bad faith, but in an unexpected way; ii) actions governed by malice with a clear intent to insult, iii) possible offense not motivated by spite (GOFFMAN, 2011). Here the problem arises as to how to discover the social attribute applicable to the você form of address and, methodologically, how to gain access to the symbolic value of human behaviors of past times.

An alternative for accessing past meaning structure is the three-scale comparative method adopted by Elias (2001) in A Sociedade de Corte and explained by Chartier in the book's preface: i) observe a form and its social function in "comparable and contemporary societies" (p. 9); ii) compare this same usage in societies distant in time and space; iii) contrast social forms and functions, taking into account conditions such as economic ethos (court society vs bourgeois society), members' profession and opposition between public and private interactions.

Within this theoretical-methodological basis, we surveyed the forms of address in Joaquim José da França Júnior's plays. The choice of a single author is a methodological strategy to avoid bias in the difference of origin, formation, and ideology, considering that world-view is expressed in and by language. A graduate of São Paulo's Law school (1862), França Jr. served as a magistrate and worked as a journalist. Dedicating himself to the study of the fine arts, he was appointed to the commission that represented Brazil at the Universal Exhibition in Vienna, Austria, in 1873 (CAFEZEIRO, 1980; FARIA, 2012; AZEVEDO, 2008).

The greatest legacy left by França Júnior concerns his dramaturgical work, primarily satirical comedies, tending in some cases to caricature and, occasionally, to the grotesque. Both plays - Ingleses na costa and Meia hora de cinismo ${ }^{8}$ ("Englishmen on the Coast" and "Half an Hour of Cynicism"), set in the city of São Paulo in the middle of the 19th century, have as their main characters students of the Law school. The plot is practically the same:

8 Meia Hora de Cinismo was his first composition and presentation. França Jr produced the comedy while attending law in São Paulo. The pay was staged for the first time on 7/17/1861. 
- | Forms of address among law students in 19th century São Paulo: symmetrical relationships

a student is in debt with a reputation for not paying and the creditor (a Jew in one case and an Englishman in the other) appears to collect the debt.

In one of the plays, one student, who is considered a rascal and a profiteer, pays his colleague's debt, under pressure from the tipstaff. In the other play, in which the English people are blamed for Brazil's economic woes, the uncle, responsible for his nephew's fortune, is blackmailed by the students and is forced to pay the debt contracted by his nephew with the English creditor. In addition to exploring the irresponsibility, cynicism, and dishonesty of the Arcade-goers, unconventional or socially accepted practices that characterize the trickster figure (DA MATTA, 1986), França Jr also highlights their lack of commitment to study, a profile studied by Adorno (1988).

The analysis of the forms of address in these two comedies comprises the first scale of comparison. For the second scale that provides temporal or spatial distance, we take the linguistic data from young bachelors in Rio de Janeiro, in the play Caiu o Ministério ("The Cabinet has been dissolved"), from 1882. This is a satire on the formation and fall of the Cabinet that "all sorts of opportunist satellites" is attentive to (COSTA, 1998), including a group of young candidates for public office. We added the play A lotação de bondes ("Tram at capacity"), in which two women get lost from their respective relatives when taking the tram to the Jardim Botânico and meet with a group of young men who are celebrating the loan that they had raised in the name of a supposed epidemic in Buenos Aires.

As a counterpoint, the forms of address used by the academics in São Paulo and Rio de Janeiro will be contrasted with those employed by young people who do not have a bachelor's degree in Maldita parentela ("Damned poor relations") (1887). Relatives who had not assimilated the court's daily social etiquette are invited to a ball for Rio de Janeiro high society to celebrate the marriage of the daughter educated at a French school (ELIAS, 1993).

Living in Prainha, where warehouses held purchased slaves, the "Damned poor relations" represent the population that did not master the codes of good manners used daily at Court. Ignoring the protocol of court ceremonial, Major Basílio's daughters greet everyone by extending their hands without previous introduction, they laugh out loud and the sisters scream among themselves in the middle of the hall. Without paying attention to the renewal in the ways of dressing, they wear old-fashioned clothing, are unkempt, muddy, and wear soaked shoes. Similarly, Cassiano Vilas Boas greets everyone with his umbrella tip pointing upwards, wears galoshes which he removes and throws under the sofa, rolls down the waist of his trousers, and demands bread and butter. Hermenegilda, Cassiano's sister, speaks loudly and declaims poetic phrases exaggeratedly, pouring 
out quotes and references to literary authorities. Ignoring the Aristotelian principle of moderation, her exaggerated flaunting of knowledge denounces her ignorance of the codes of refined behavior.

The three comparisons are based on the models of Brown and Gilson (1960), seeking to observe similar relationships of solidarity and non-solidarity in symmetrical relations, to focus on the sensitivities that activate deviant forms of address.

\section{Forms of address in symmetrical relationships}

From the panoramic analysis of the forms of address in 14 plays by França Júnior, we observe the absence of você in four comedies. In the other plays, the use of você is conditioned by social or stylistic factors, such as, the categorical use of você for slaves, children, and Italian people, which stands out as a descending asymmetric relationship. In symmetrical relationships, você occurs between cousins. Aside from the importance of these social aspects, the use of você is conditioned stylistically, which we will try to show in the context of symmetrical relations of solidarity and non-solidarity. For this, we present the character chart below and its characteristics to discuss the linguistic usage later. Let us start with the plays that make up the first comparative table, adapting the methodology proposed by Elias (2001) to the forms of address. Elias studied the remodeling of the affectivity that involves the men of a court society; we intend to study the forms of address among students with higher education being prepared to assume administrative and social positions in the court society of the Brazilian Empire ${ }^{9}$.

Considering the author's attention to the forms of address, as it will be seen throughout this study, the fact that the comedy Meia hora de cinismo (1861) was written when the author was still attending the São Paulo Law School, and the comedy Ingleses na costa (1864), from two or three years later, it is quite plausible to support the hypothesis of a representation very close to actual students' speech:

9 The republican government took place in 1889. 
- Forms of address among law students in 19th century São Paulo: symmetrical relationships

Table 1. Characters and their characteristics per play

\begin{tabular}{l|l|l|l}
\hline \multicolumn{2}{l|}{ Ingleses na costa } & Meia hora de cinismo \\
\hline CHARACTERS & CHARACTERISTICS & CHARACTERS & CHARACTERISTICS \\
\hline Félix & 5th year law student & Macedo & 4th year law student \\
\hline Silveira & 2th year law student & Neves & 3th year law student \\
\hline Feliciano & - & Nogueira & 2th year law student \\
\hline Lulu & - & Trindade & Freshman \\
\hline Ritinha & 22 years age & Frederico & Preparatory school student \\
\hline Luís de Castro & Félix's uncle & Jacó & Merchant \\
\hline Teixeira & $\begin{array}{l}\text { Creditor, nickname: } \\
\text { Englishman }\end{array}$ & Criado & Servant \\
\hline
\end{tabular}

Source: Self elaboration

In symmetrical relations in Ingleses na costa (1864), the address is carried out by the pronoun tu among the academics (solidarity relationship) and by o senhor ("sir", lit., "the gentleman") among those who are not members of the groups of friends (non-solidarity relationship $)^{10}$ :

Table 2. Ingleses na costa: address pronouns

\begin{tabular}{l|l|l|l|l|l}
\hline \multicolumn{1}{c|}{ CHARACTERS } & \multicolumn{6}{c}{ SYMMETRIC RELATIONS } \\
\hline & Félix & Silveira & Feliciano & Teixeira & Luís de Castro \\
\hline Félix $^{11}$ & $/$ & $(\mathrm{tu})$ & $(\mathrm{tu})$ & - & - \\
\hline Silveira & $\mathrm{Tu}$ & $/$ & $\mathrm{Tu}$ & O senhor & O senhor \\
\hline Feliciano & $\mathrm{Tu}$ & $\mathrm{Tu}$ & $/$ & O senhor & - \\
\hline Teixeira & - & O senhor & - & - & - \\
\hline Luís de Castro & - & O senhor & - & - & - \\
\hline
\end{tabular}

Source: Self elaboration

In Meia hora de cinismo (1861), the use of o senhor that normally typifies interpersonal relationships characterized by non-sympathetic symmetry also appears in symmetrical sympathetic relationships (between students) installing a framework of variation in the forms of address:

10 The Academics address girls as $t u$, but girls do not dare to use the same expression in return. It is not clear whether the asymmetric address is due to gender, to a hierarchical situation among the friends, or, perhaps to the girls' profile as women who did not fit the civilized molds of the period.

11 Felix to Felix ( / ) signs no aplication; Félix to Silveira (tu) signs use of null-subject of 2nd singular person tu; Félix to Teixeira (_) signs that there was no dialogue between them. Silveira used tu to Félix and $o$ senhor to Teixeira, and so on. 
Table 3. Meia Hora de Cinismo: Address pronouns

\begin{tabular}{|c|c|c|c|c|c|c|}
\hline CHARACTERS & \multicolumn{6}{|c|}{ SYMMETRIC RELATIONS } \\
\hline & Trindade & Nogueira & Neves & Macedo & Frederico & Jacó \\
\hline Macedo & $\begin{array}{l}\text { Tu } \\
\text { 3SGIMP } 12\end{array}$ & $\begin{array}{l}\text { (tu) }{ }^{13} \\
\text { 3SGIMP }\end{array}$ & - & / & - & O Senhor \\
\hline Nogueira & $\begin{array}{l}\text { Tu } \\
\text { O doutor }\end{array}$ & l & (tu) & (tu) & (tu) & O Senhor \\
\hline Trindade & l & $\begin{array}{l}\text { Tu } \\
\text { O Senhor } \\
\text { Você }\end{array}$ & - & O Senhor & $\begin{array}{l}\text { O Senhor } \\
\text { Você }\end{array}$ & O Senhor \\
\hline Frederico & $\begin{array}{l}\text { (tu) } \\
\text { Você }\end{array}$ & Tu & - & - & / & - \\
\hline Jacó & O Senhor & $\begin{array}{l}\text { O Senhor } \\
\text { Doutor } \\
\text { Vossa Senhoria }\end{array}$ & - & - & - & I \\
\hline
\end{tabular}

Source: Self elaboration

An example of an affective stance is the dialogue below. Being aware of the good results of the exams performed by Trindade, the freshman, Nogueira called him doctor for threatening his face. In doing so, a confrontational ethos came in. In a community of practice where rights are in debate, language socialization requires practice on confronting arguments. In fact, "language socializes not only through its symbolic content but also through its use" (OCHS, p. 408). Being not sufficiently prepared for this situation, Trindade relies on his sensibility and expresses aggressive behaviour:

(1) Nogueira (Pondo uma cadeira de permeio)_ Não quer sentar-se, doutor?

Trindade_Miserável!

Frederico _ $(T u)$ Deixa-te de queimações estúpidas, Trindade, o Nogueira não tem culpa da hipótese que tomaste.

Trindade_Também você, sô gaiatão, quer divertir-se à minha custa? Vamos lá, não tem mais para nada para dizer? Ora, que eu seja nesta casa debicado até por um bicho! Olhem por favor para aquela cara.

Frederico _ Não é lá das piores, não é das mais feias.

Trindade _ O senhor acha que eu sou o palito cá da casa?

Nogueira (Para os dois)_ Psica, psica: segura Minerva. (Para Trindade) Pega turbante. (Para Frederico) Psica, psica.

Trindade_Psica, sô miserável, diz-se aos cães e cão é você.... (MHC, Cena 4) (our underlining)

12 3rd. singular person. Imperative form.

13 The pronouns in parentheses represent a null subject. 
- | Forms of address among law students in 19th century São Paulo: symmetrical relationships

\author{
Nogueira (Putting a chair in between)_Wouldn't you care to sit down, doctor? \\ Trinity_Scoundrel! \\ Frederico _ Stop these stupid worries, Trindade, Nogueira is not to blame for the hypothesis you \\ took.
}

Trinity _ You too, want to have fun at my expense, mister playful? Come on, don't you have anything else to say? Well. May I even be pecked at by a bug in this? Please look at that face.

Frederick_It is not one of the worst; It's not one of the ugliest.

Trinity_Do you think I'm the toothpick of the house, sir?

Nogueira (For both)_ Hush, hush: hold Minerva. (to Trinity) Get a turban. (to Frederico) Hush, hush.

Trinity _ Hush, master scoundrel, is what's said to dogs and you are a dog.... (MHC, Scene 4)

The passage shows that você and $o$ senhor in the context of familiarity also add stylistic effect encoding anger at the hearer. It is not sought to establish a mere distancing, but to provoke and threaten the hearer's face (GOFFMAN, 2011). So, where is the difference between o senhor and você? Is the symbolic value of você the same in a provincial environment, which characterizes the city of São Paulo in the middle of the 19th century, and in a court environment that characterizes Rio de Janeiro?

Taking as the second scale of comparison the play Caiu o ministério (1882), in which the young bachelors in Rio de Janeiro scrutinise the composition of the Ministries to apply for a place in some secretariat, one perceives no difference in linguistic behavior concerning the law students in São Paulo, either in the solidarity agreement (tu) or in the non-solidarity (o senhor) tract.

Excluding the figures who occupy positions in the political and administrative spheres (Felício, Anastácio, Monteirinho, Felizardo, and Pereira) among whom there exists the rigor of address protocols - "Vossa excelência" Your Excellency-, we find only o senhor in the framework of non-solidary symmetrical interpersonal relationships.

In non-solidary relationships, the use of $o$ senhor is categorical, occurring between female and male gender elements and between different age groups. Only one form of address does not match in this context: the use of "Your Excellency" to address Filomena when her husband changes his socio-political level, reaching the position of minister. It is worth remembering that in the play analyzed this formula is used out of respect for protocol, as observed in the relations between senators and ministers. Regarding the expression voce, it is not recorded in the interpersonal relationship that involves the dimension of symmetrical and non-symmetrical solidarity. 
Expanding this second scale of comparison, we observed the address in another play, A lotação dos bondes, in which the young people who form the group "Devil's Lieutenants" address themselves with the pronoun tu (Ernesto to Vitorino; Magalhães to Carneiro). Among the non-solidary, the address is carried out with the formal form o senhor (Ramiro to Pimenta and vice versa; Pimenta to Camilo and vice versa; Ramiro to Magalhães). As a stylistic use, the address "Your Excellency" appears in Camilo's first approach to Josefa and Elvira as a strategy of seduction. In these symmetrical, solidary and non-solidary relationships, the employment of você was also not registered.

To compose the third comparative scale, we take as a counterpoint the play Maldita Parentela in which França Júnior exposes the linguistic behavior of different social types. Regarding the symmetrical relations, as outlined by Brown and Gilman (1960), there is linguistic variation in the speech of the young people present at the ball in the city of Rio de Janeiro, distributed in pairs: on the one hand, the lovers Marianinha and Dr. Aurelio, who follow the customs of the Court; on the other, the sisters Cocota and Laurindinha, the siblings Hermenegilda and Cassiano and the cousins Laurindinha and Cassiano, representatives of groups that do not align with this "decorum".

Table 4. Maldita parentela: pronouns of address among lovers, cousins and siblings

\begin{tabular}{l|c|l|l|l|l}
\hline & Marianinha & Dr. Aurélio & Laurindinha & Cocota & Cassiano \\
\hline Marianinha & $/$ & Tu & - & - & - \\
\hline Dr Aurélio & Tu & $/$ & - & - & - \\
\hline Laurindinha & - & - & $/$ & Tu / Você & Você \\
\hline Cocota & - & - & Você & $/$ & - \\
\hline Cassiano & - & - & Você & - & $/$ \\
\hline Hermenegilda & - & - & - & - & Tu \\
\hline
\end{tabular}

Source: Self elaboration

The lovers - Marianinha and Dr. Aurelio - who represent "civilized" young people treat each other as $t u$, as is the case in the exchange between siblings, particularly in the speech of Hermenegilda, whose identity is marked by prolixity, rhetorical devices such as quotations and literary references. Her linguistic behaviour reveals a socially and culturally situated activity whereby there is no place for feelings explosion. So, when her brother Cassiano challenges Guimarães to a duel she obeys court etiquette and kindly asks him not to shed the blood of her pretender. In doing so, she uses the familiar tu to address her brother. 
- | Forms of address among law students in 19th century São Paulo: symmetrical relationships

(2) Hermenegilda (Pondo-se de permeio)_Cassiano Vilasboas, meu irmão, não (tu) derrames o sangue deste homem. (MP, Cena 21)

Hermenegilda (She got it in the way)_Cassiano Vilasboas, my brother, do not spill the blood of this man. (MP, Scene 21)

It is also used among the rustic sisters in directive speech acts (AUSTIN, 1990), which leads us to infer that the trait of intimacy for tu exists for both groups, the upper class that represents the court society and the outsider:

(3) Cocota _ Um diabo de um mono assim que encontrei na sala tirou-me para uma quadrilha e entendeu que devia tomar-me para seu palito. Depois de me ter dito uma porção de asneiras, perguntou-me se eu não era da Cascadura, e acabou por pedir-me o molde do meu penteado.

Laurindinha _ Ah! Ah! Ah! E tu encavacaste com isto? (MP, Cena 13) (our emphasis)

Cocota_A devil of a monkey as soon as I met him in the hall he took me to dance a quadrille and assumed that he should mock me. After having told me a number of idiocies, he asked me if I wasn't from Cascadura, and ended up asking me for the mold of my hairstyle.

Laurindinha _Oh! Oh! Oh! And you dug in with this? (MP, Scene 13)

The case of the rustic cousins (Laurindinha and Cassiano) is different: they call themselves você. Laurindinha's raucous laughter could lead us to assign the use of você between the cousins to the non-incorporation of codes of conduct that typify a "civilized" society. For them, você, as any interactional behaviour, didn't laden with politeness because they ignored the ideal of urbanitas of the court environment. Although Cassiano Vilas Boas reports the negative comments from other young women about her dress to his cousin, he does not endorse them, so among cousins, the employment of você is not associated with negative values.

(4) Laurindinha (Rindo-se às gargalhadas)_Ah Ah! Ah! Você já viu, primo, que súcia de feiosas, todas caiadas e a fazerem umas cortesias muito fora de propósito! (arremedando)

Cassiano _ E que linguinhas! Uma delas que dançou perto de mim estava falando do seu balão.

Laurindinha_ O que é que ela podia dizer do meu balão?

Cassiano _ Eu lá sei; disse que você estava estufada, como uma pipoca.

Laurindinha_Ah! Ah! Ah! E elas são umas escorridas; parecem uns chapéus de sol fechados! (MP, Cena 12) 
Laurindinha (Laughing with laughter)__Ha! Ha! H! You'll have already seen that gang of ugly girls, cousin, all whitewashed and doing some very off-purpose amenities! (mocking) Cassiano_And so sharp-tongued! One of them who danced next to me was talking about your balloon dress.

Laurindinha _ What could she say about my dress?

Cassiano_Idon't know; She said you were puffed up, like popcorn.

Laurindinha_Oh! Oh! Oh! And they're beanpole girls; They look like closed sun hats! (MP, Scene

12)

As você occurs in all interlocutions between cousins, it is plausible that this form of address is marked with the distance feature. In this sense, the use of você between cousins shows that, for the social class that Cassiano and Laurindinha represent, this interpersonal relationship cannot be embedded within the symmetric solidarity category.

For outsiders, você is part of the behavioral deviations of cousins to the etiquette of "civility", creating a stigma around the use of this form of address and, consequently, the prestige of $t u$. However, the negative evaluation of você by etiquette bias is not enough to explain the variation between the sisters, because neither respects the codes of conduct of a "civilized" society. The idea of distance, of course, also does not apply to the sisters, after all, there are no social differences between them. The use of você is motivated by another factor that requires looking from another perspective, that of sensitivities. When the two forms ( $t u$ and você) are compared one can observe the influence of mood in choosing the form to be used in interpersonal relationships (See examples 3 and 4 above).

A certain phlegmatic attitude of the sisters triggers $t u$. Upon hearing Cocota's account of the offense received, Laurindinha laughs and retorts with "never mind", "don't worry about it", "let it be", which makes the use of the pronoun $t u$. In turn, a choleric attitude activates the use of você in an illocuttonary act of accusation and threat, with a breach of decorum. This stylistic "effect of an omen" (LUFT, 1957) is the same that is observed in Trindade's speech to Frederico and Nogueira in the play Meia Hora de Cinicismo (See example 1 above).

The form o senhor can also be used in the illocutionary act of rebuke and accusation, but, unlike você, without breaking decorum. In the social interaction in which a symmetrical relationship is installed, addressing someone with o senhor causes the opponent's removal and installs a relationship of superiority that, because it is not the result of a new social composition, is interpreted as a fictitious elevation. The pronoun 
- | Forms of address among law students in 19th century São Paulo: symmetrical relationships

o senhor used by Trindade to Frederico, a preparatory course student, that is, a person who did not even walk into the doors of law school, behavioral conventions and, with this, provokes the feeling of displacing the opponent, of making him feel out of reality. This displacement has the effect of signalling a reprehensible attitude in the hearer, a call to reality, so that the opponent reanalyzes himself and situates himself in the real world, being put in his proper place ${ }^{14}$.

The use of você is different. The above dialogue (1) brings the nonstandard form of address sô (sir) as a clue to reach the meaning of você. Uttered by Trindade, more than indicating its origin, sô indicates a strategy used by the upper social layers to cause humor, playfulness, and, at the opposite end of the scale, disdain and contempt (LUFT 1957). Followed by names with a negative charge (sô gaitão; sô miserável) in the appositive form, você acquires, metonymically, the function of disqualifying the addressee. To save his own face, since his colleagues used to tease him for being a freshman and, above all, a "caxias" (efficient student), Trindade uses one of the aggressive methods of face preservation. He offends them safely, that is, he treats them as você, because he knows that colleagues, who live on jokes, are willing to ignore the affront.

Thus, among colleagues, the pronoun tu gives way to você as a strategy for depreciating the addressee in a situation that breaks behavioral decorum owing to Trindade's anger. Such treatment is not just reprehensible. If it were, it would be enough to call friends o senhor to call them to reality. The use of você, on the contrary, expresses the psychological disorder of those who use it and provokes, to create a carnival image of a temporal release of affairs (BAKHTIN, 1987) as a place of the interlocutor. It constitutes an act of moral forfeiture that does not have the function of calling to reality, but rather of expelling from the social body, as can occur with convivial insults of the type "Get lost!" or "Go to hell!".

This demotion using você is not restricted to symmetric solidarity relationships. At this point, it is interesting to confront the change in address from o senhor to $t u$, which occurs between Basilio and Dr. Aurelio, and the shift from o senhor to você, between Guimarães and Cassiano.

\footnotetext{
14 A similar effect is obtained in Ingleses na costa, in which the uncle calls his nephew o senhor: Félix - Meu tio, olhe a canastra. Luís de Castro - E tem o arrojo de não corar em minha presença! Quem julga o senhor que eu sou? (IC, Cena 13) Félix - Uncle, watch out for the police. Luís de Castro - And you have the audacity not to blush in my presence! Who do you think I am, sir? (IC, Scene 13)
} 
The use of $t u$ among those who called themselves $o$ senhor occurs the moment Basilo discovers that Dr. Aurelio is his son. Thus, tu represents the alteration of the social bond between Dr. Aurelio and Basilio, establishing the relationship of downward asymmetry. The selection of você by Guimarães when questioning Cassiano Vilasboas is motivated by an alleged act of offense or dishonor. Seeing Guimarães at his sister's feet, Vilasboas challenges him to prepare for a duel, to which Guimarães retorts that it was not necessary to prepare to duel with him. This drawdown is highlighted with the use of você:

(5) Cassiano _ Prepare-se para bater-se comigo, senhor.

Guimarães_ Pois para bater-me com você é preciso preparar-me? (MP, Cena 21)

Cassiano_Prepare yourself to duel with me, sir.

Guimarães_And is it necessary to prepare myself to duel with you? (MP, Scene 21)

The adoption of você does not lead to a change in the type of social bond. The symmetrical relationship is maintained, but behavioral conventions are violated because it exposes sensitivities. This violation is not a mere rebuke or call to reality, but the mobilization of a familiar language in the public square (BAKHTIN, 1987) to attack in a crude way the opponent, to demoralize him. Guimarães could have accepted the duel and marked his date according to custom, but preferred to duel on the spot to ridicule Cassiano Vilas Boas, his opponent. Triggering the Shakespearian metaphor of the tailor (ORMSBY-LENNON, 1991), Guimarães chooses as a weapon the topos "the tongue is the garment of thought" and associates "you" with the figure without shoes (Cassiano had removed them and placed them under the couch). Written and set in the period before the abolition of slavery, the play represents the imaginary of the time, when bare feet (SCHWARCZ, 2012) referred to the figure of the slave, a being regarded as civilly incapable, whom one called você.

Finally, the change from $A$ senhora (the lady, madam) to a menina (the girl) in Guimarães' speech to Marianinha is a clue of his lack of skill and faulty knowledge of etiquette in selecting a respectful but quasi-familiar form (the usage of the first name) in a symmetrical non-solidary relationship.

(6) Guimarães _ Ah! Eu não sou homem de etiquetas, digo o que sinto. Fiz um bom negócio e desabafo com a menina, que é uma pessoa a quem amo com todas aquelas. Também se não gostasse da senhora, dizia-lhe logo nas ventas; eu para isso sou bom. (MP, Cena 10)

Guimarães_Ah! I'm not an etiquette, I say what I feel. I made a good deal and let offsteam with the girl, who is a person whom I love with all those ones. Also, if I didn't like you, ma'am, I'd tell you right to your face; I'm good at that. (MP, Scene 10) 
- | Forms of address among law students in 19th century São Paulo: symmetrical relationships

The comparative method in the three scales of the forms of address, from the cutout of symmetrical interpersonal relationships, allowed mapping the linguistic variation in environments of similar social forces (the students of the São Paulo Law School and the bachelors in Rio de Janeiro), but in geographically and socially distant places (the Provinces and Court), contrasting them with popular groups. The results lead to the following tables synthesising the forms of address for symmetrical relationships (solidarity and non-solidarity):

Table 5. Forms of address as social ties

\begin{tabular}{l|l|l|l|l}
\hline & Social type & Form & Personal relationships & Examples \\
\hline & Popular & Você & $\begin{array}{l}\text { Non-solidarity } \\
\text { symmetry }\end{array}$ & Among cousins \\
\hline SOCIAL & Non popular & Tu senhor & $\begin{array}{l}\text { Solidarity symmetry } \\
\begin{array}{l}\text { Non-solidarity } \\
\text { symmetry }\end{array}\end{array}$ & Among siblings \\
\hline & & Tu & Solidarity symmetry & Among friends \\
\hline
\end{tabular}

Source: Self elaboration

Table 6. Forms of address as behaviors

\begin{tabular}{|c|c|c|c|c|c|}
\hline & Type & \multicolumn{2}{|l|}{ Form } & Function & Personal relationships \\
\hline & Sensitivity & \multicolumn{2}{|l|}{ O senhor } & $\begin{array}{l}\text { Higher standing: } \\
\text { rebuke act }\end{array}$ & Solidarity symmetry \\
\hline \multirow[t]{5}{*}{ STYLISTIC } & & \multicolumn{2}{|l|}{ Você } & $\begin{array}{l}\text { Lower standing: } \\
\text { dismissal act }\end{array}$ & $\begin{array}{l}\text { Solidarity symmetry and } \\
\text { non solidarity }\end{array}$ \\
\hline & \multirow{2}{*}{ Formality } & \multirow{2}{*}{ Pop } & A senhora & (+) Detachment & Non-solidarity symmetry \\
\hline & & & A menina & (-) Detachment & Non-solidarity symmetry \\
\hline & & \multirow{2}{*}{ Non pop } & $\begin{array}{l}\text { Vossa } \\
\text { Excelência }\end{array}$ & (+) Reverence & Non-solidarity symmetry \\
\hline & & & A senhora & (+) Detachment & Non-solidarity symmetry \\
\hline
\end{tabular}

Source: Self elaboration

Used in non-solidarity symmetry between cousins of the lower classes, você was probably negatively evaluated by the non-low group, because, although the populous used it among themselves neutrally, it was also employed by both social groups to encode lower standing when there was a change in mood. In other words, the knowledge of its offensive function was the instrument that provided the negative evaluation of its use in neutral form by the non-low group. 
In another perspective, você and o senhor used for attacking someone exhibits different values. This is because even if both are applied to asymmtetrical relations, $o$ senhor is used by inferior to superior and você by superior to inferior. If we adopt the idea that good is up and bad is down (LAKOFF; JOHNSON, 1980), it seems clear that você was more offensive. Standing the low in a Bakhtinian way, it was not reducible to the lower classes, the scholar Trindade also used it to defend himself from his friends' bullying. In these terms, there were no stylistic differences between the academics of São Paulo and the bachelors of Rio de Janeiro, or the lower class young people when they used você to affective stance, to express the feeling of anger that should be under control in a civilized world (ELIAS, 1993). By ruling out stylistic use, você was a linguistic indicator, a shibboleth that denounced low status.

In short, the negligible details regarding the forms of address reveal that $t u$ is not interchangeable with você and você is not interchangeable with o senhor in the attitudes expressed by the characters. It is true that, as a symbolic action, the linguistic behavior that involves choosing ways of addressing one's interlocutor interweaves the social and the stylistic. However, these two fields cannot be measured by the same yardstick, as they do not have the same set of forces. In the social sphere, forms of address configure the bonds between interlocutors regulated by social factors; in the stylistic sphere, they inscribe sensitivities in the form of moods and behavioral adjustments/misfits (including the issue of etiquette).

\section{Final considerations}

The analysis pointed out that $t u$ and você were used for symmetrical interpersonal relationships. However, this doesn't mean that these forms were interchangeable. The variables are related to class identity in the sense that these two forms compete in symmetrical and solidary relations among elements of a lower class. The option for você within this context, though, is excluded from the upper one. This restriction points that você stigmatize the speaker. Furthermore, according toWeinrich's (1986, p. 16) rule governing politeness, in the presence of two variables for a given situation, the "fuzzier form" is considered politer than the delimited one. This signals that the address form $t u$, the fuzzier one, is politer than você. This symbolic value of the address forms is clearer in the context of another subevent: the affective stance. Indeed, você is uttered quite emphatically to express the feeling of anger with a clear intent to insult the hearer as a defensive position to preserve face from some threat. 
- | Forms of address among law students in 19th century São Paulo: symmetrical relationships

Nonetheless, the address form o senhor also expresses emphatically the feeling of anger for the same defensive purpose. Both o senhor and você perform aggressiveness and may be extended with yelling. But the first one is a scolding less offensive due to the fact it is also used in asymmetrical relations by inferior to superior; conversely, você is used in asymmetrical relations by superior to inferior. Metaphorically, down is bad, then the use of você between equals was a very aggressive way to threaten the other's face.

Finally, the focus on the survey of meanings and not of regulating laws for using the address forms allowed us to capture meanings of the use of você not achieved by statistical researches that ignore the affective stance, a dimension socio-culturally linked to the linguistic forms. Among cultured people, the address form você is not about the type of social bond. It has only a stylistic function, in the sense that it is an aggressive approach and, in doing so, exposes sensitivities. This violation is not a mere reprehension or call to reality, but the mobilization of a familiar language in the public square (BAKHTIN, 1987) to attack in a crude way the opponent, to demoralize him. In the case of the students of Law, this attack was a kind of exercising the control of own emotions in face of disputes and objections, a necessary knowledge to be part of the legal world. After all, "the process of language socialization will be related to the capacity of language practices to index sociocultural information" (OCHS, 1996:409).

\section{References}

ABREU, S. A. Os aprendizes do Poder. O Bacharelismo Liberal na Política Brasileira. Rio de Janeiro: Paz e Terra, 1988.

AUSTIN, J. L. Quando dizer é fazer. Porto Alegre: Artes médicas, 1990.

AZEVEDO, M. Muito siso e pouco riso. São Paulo: Linear B/FFLCH-USP, 2008.

BAKHTIN, M. A cultura popular na Idade Média e no Renascimento: o contexto de François Rabelais. São Paulo: Hucitec/UNB, 1987.

BROWN, R.; GILMAN, A. Pronouns of Power and solidariety. In: SEBEAOK. A. (org.). Style in Language. Massachussets: MIT Press, 1960.

BIDERMAN, M. T. C. Formas de tratamento e estruturas sociais. Alfa, v. 18-19, p. 338-381, 1975. 
CARREIRA, M. H. Politeness in Portugal: how to address others. In: HICKEY, L.; STEWART, M. Politeness in Europe. Clevedon-Buffalo-toronto, Multilingual Matters, 2005. p. 306-316.

CAFEZEIRO, E. Teatro de França Júnior. Rio de Janeiro: MEC/SNT/FNA, 1980.

CINTRA, L. Sobre formas de tratamento na língua portuguesa: ensaios. Lisboa: Horizonte, 1972.

COSTA, I. A classe da comédia de França Júnior. In: COSTA, I. Sinta o drama. Petrópolis: Vozes, 1998. p. 157-175.

DA MATTA, R. O que faz do Brasil Brasil. Rio de Janeiro: Rocco, 1986.

DUARTE, M. E. Do pronome nulo ao pronome pleno: a trajetória do sujeito no português do Brasil. In: ROBERTS, I.; KATO, M. (org.). Português Brasileiro: uma viagem diacrônica. Campinas: Ed. da UNICAMP, 1993.

ECKERT, P. Linguistic Variation as social practice. Oxford: Blackwell, 2000.

ELIAS, N. O processo civilizador - Uma história dos costumes. Rio de Janeiro: Zahar, 1993.

ELIAS, N. A sociedade de corte. Rio de Janeiro: Zahar, 2001.

FARACO, C. O tratamento Você em português: uma abordagem histórica. Fragmenta, Curitiba: Ed. da Universidade Federal do Paraná, n. 13, p. 51-82, 1996.

FARIA, J. História do Teatro Brasileiro. São Paulo: Perspectiva/SESC, 2012.

FREITAS, S. Presença portuguesa em São Paulo. São Paulo: Imprensa Oficial, 2006.

GEERTZ, C. A interpretação das Culturas. Rio de Janeiro: LTC, 2011.

GINZBURG, C. Sinais. Raízes de um paradigma indiciário. In: GINZBURG, C. Mitos, Emblemas, Sinais. 2. ed. São Paulo: Companhia das Letras, 1989.

GOFFMAN, E. Ritual de interação. Ensaios sobre o comportamento face a face. Petrópolis: Vozes, 2011. 
- | Forms of address among law students in 19th century São Paulo: symmetrical relationships

KLEIN, H. A integração social e econômica dos imigrantes portugueses no Brasil no fim do século XIX e no século XX. Revista Brasileira de Estudos da População. São Paulo, v. 6, n. 2 , p. 17-37, 1989.

LAKOFF, G.; JOHNSON, M. Methaphors we life by. Chicago: University of Chicago, 1980.

LOPES, C. R.; DUARTE, M. E. De "vossa mercê" a você: análise da pronominalização de nominais em peças brasileiras e portuguesas setecentistas e oitocentistas. In: BRANDÃO, S.; MOTA, M. (org.). Análise contrastiva de variedades do português: primeiros estudos. Rio de Janeiro: In Folio, 2003.

LOPES, C. R.; DUARTE, M. E. Notícias sobre o tratamento em cartas escritas no Brasil dos séculos XVIII e XIX. In: RAMOS, J.; ALKMIM, M. (org.). Para a história do português brasileiro. v. V. Estudos sobre mudança linguística e história social. Belo Horizonte: Ed. FALE/UFMG, 2007.

LUFT, C. Tratamento depreciativo. Revista Brasileira de Filologia, Rio de Janeiro: Acadêmica, v. 3, tomo II, p. 193-207, 1957.

MACHADO, A. As formas de tratamento no teatro do Rio de Janeiro dos séculos XIX e XX. Cadernos de Estudos Linguísticos, Campinas, v. 60, n. 93, p. 647-668, 2018.

MENON, O. O sistema pronominal do português do Brasil. Revista de Letras, v. 44, p. 91106, 1995. Disponível em: https://revistas.ufpr.br/letras/article/view/19069. Acesso em: 15 fev. 2021.

MENON, O. A história de você. In: GUEDES, M.; BERLINCK, R. de A.; MURAKAWA, C. de A. A. (org.). Teoria e análise linguísticas: novas trilhas. Araraquara: UNESP, 2006. p. 99-160.

MEYERHOFF, M.; HOMES, J. The Community of Practice: Theories and methodologies in language and gender research. Language in Society, Cambridge: Cambridge University Press, v. 28, n. 2, p. 173-183, 1999.

NASCENTES, A. O tratamento de 'você' no Brasil. Revista Letras, v. 5/6, p. 114-122, 1956. Disponível em: https://revistas.ufpr.br/letras/article/view/20034. Acesso em: 15 fev. 2021. 
OCHS, E. Linguistic resources for socializing humanity. In: GUMPERZ, J.; LEVINSON, C. (ed.). Rethinking linguistic relativity. Cambridge: Cambridge University Press, 1996. p. 407-437.

OLIVEIRA, M. A naturalização dos portugueses e a invenção da marca identitária. In: FIGUEIREDO, C.; ARAÚJO, E. (org.). Diálogos com Ilza Ribeiro sobre gramática e história da língua portuguesa. Salvador: EDUFBA, 2015. p. 225-249.

OLIVEIRA, M.; RAMOS, J. Vetores de homogeneidade e heterogeneidade: questões linguísticas. In: RAMOS, J.; OLIVEIRA, M. (org.). Dialetação e povoamento: da história linguística à história social. São Paulo: Contexto. p. 234-255. (to appear)

ORMSBY-LENNON, H. Do xibolé ao apocalipse: falares quacres durante a revolução puritana. In: BURKE, P.; PORTER, R. (org.). Linguagem, indivíduo e sociedade. São Paulo: Unesp, 1991. p. 101-152.

RIBEIRO, P. Língua e sociedade: a ordem na escola republicana paulista. 2015. Tese (Doutorado em Letras) - Faculdade de Filosofia, Letras e Ciências Humanas, Universidade de São Paulo, São Paulo, 2015.

RIBEIRO, P. A ordem de constituintes sentenciais no português paulista. 2010.

Dissertação (Mestrado em Filologia e Língua Portuguesa) - Faculdade de Filosofia, Letras e Ciências Humanas, Universidade de São Paulo, São Paulo, 2010.

RUMEU, M. C. A implementação do 'Você' no Português Brasileiro Oitocentista e ecentista: um estudo de painel. 2008. Tese (Doutorado em Letras) - Faculdade de Letras, Universidade Federal do Rio de Janeiro, Rio de Janeiro, 2008.

SCHWARCZ, L. As barbas do imperador: D. Pedro II, um monarca nos trópicos. São Paulo: Companhia das Letras, 2012.

SILVA, H. S. O lugar da língua na São Paulo transformada: os usos linguísticos dos intelectuais republicanos paulistas. 2012. Tese (Doutorado em Filologia e Língua Portuguesa) - Faculdade de Filosofia, Letras e Ciências Humanas, Universidade de São Paulo, São Paulo, 2012. 
- | Forms of address among law students in 19th century São Paulo: symmetrical relationships

SILVA, A.; BARCIA, L. "Vossa mercê, você, vós ou tu? A flutuação de formas em cartas cariocas dos séculos XVIII e XIX". Ao Pé da Letra, v. 4, n. 1, p. 21-30, 2000.

SILVA, M. B. N. da. Documentos para a História da Imigração Portuguesa no Brasil (1850-1938). Rio de Janeiro: Editorial Nórdica, 2012.

WEINRICH, P. Identity development in migrant offspring: Theory and practice. In: EKSTRAND, L. H. (ed.). Ethnic minorities and immigrants in a crosscultural perspective. Lisse: Swets \& Zeitlinger, 1986.

COMO CITAR ESTE ARTIGO: OLIVEIRA, Marilza de; SOARES, Enedino. Forms of address among law students in 19th century São Paulo: symmetrical relationships. Revista do GEL, v. 18, n. 1, p. 145-168, 2021. Disponível em: https://revistadogel. gel.org.br/

Submetido em: 11/11/2020 | Aceito em: 23/01/2021. 